\title{
BIODIVERSITY OF THE MADUGANGA MANGROVE WETLAND
}

\author{
CNB Bambaradeniya, SP Ekanayake, LDCB Kekulandala, \\ RHSS Fernando, VAP Samarawickrena, TGM Priyadhadharshana \\ and KBR Ranawana \\ IUCN - The World Conservation Union. Horton Place, Colombo 07
}

The Maduganga estuary and mangrove islets are a complex coastal wetland ecosystem situated within the two Divisional Secretariats of Balapaitiya and Karandeniya in the Galle District of Southern Sri Lanka. The total area of the estuary is 915 ha, of which 770 ha consist of open water, while islands account for $145 \mathrm{ha}$. With the view of safeguarding the ecological functions, resources and values of the Maduganga estuary for conservation and future sustenance of biodiversity, IUCN Sri Lanka carried out a systemat c assessment of biodiversity in Maduganga. A six-month field survey was conducted from May to October 2000. Field sampling was carried out at fortnightly intervals' each sampling session spanning over six continuous days. The Maduganga ecosystem was divided into six major s rata based on the occurrence of different vegetation types, human activities and a hypothetical salinity gradient. These strata were sampled for fauna and flora in a systematic manner, using standard techniques. The threats to biodiversity were also assessed.

The survey revealed that the Maduganga wetland consists of 10 major wetland vegetation types. These vegetation types harboured a total of 303 species of plants belonging to 95 families. The total plant species included 19 endemics, 8 nationsliy threatened species and 9 invasive alien species. Based on the extent of occurrence (ha), mangroves and mangrove mixed swamps were the dominant wetland vegetation types in Madugangl. In addition to these wetland vegetation types, three major terrestrial vegetation types are alsc found in the islands and the surrounding mainland area of the Maduganga estuary. Perenniall crops (mainly cinnamon) dominated the terrestrial vegetation types. A total of 98 plant species were recorded from the multi-species home gardens. When considering the species richnes of flora in different wetland vegetation types, mangroves harboured the highest number of species, closely followed by mangrove mixed swamps. Maduganga estuary harbours a small population of a very rare, threatened mangrove species Lunmitzera littorea. A total of 248 species of vertebrate fauna, belonging to 121 families were recorded from Maduganga. These included 20 species $(8 \%)$ of endemics, while 30 species $(12 \%)$ are considered as nationally threatened. The native vertebrate fauna of Maduganga represents $30 \%$ of Sri Lanka's native inland vertebratt. species.

Maduganga, perhaps one of the last remaining tracis of pristine mangrove forest in Sri Lanka with a rich biodiversity, now appears to be threaten w with the same predicament that many of the island's mangroves now find themselves in, owizg to increasing human activity. At present, this wetland is not a protected area under any government department. Therefore, it is envisaged that the findings of this survey will contribute to the a nservation of this unique coastal wetland.

Proceedings of the Seventh Annu,1 =orestry and Environment Symposium 2001 of the Depa tinent of Forestry and Environmental Sclence Liniversity of Sri Jayewardenepura, Sri Lanka 